\title{
IAMJ
}

INTERNATIONAL

AYURVEDIC

MEDICAL JOURNAL

ISSN: 2320-5091

Impact Factor: 6.719

\section{EVALUATION OF NITYA PRAYUNJEET AAHARA DRAVYA OF AYURVEDA AND ITS RESEMBLANCE TO BALANCED DIET IN CURRENT SCENARIO}

\author{
Dogra Akanksha', Jagota Ankush ${ }^{2}$
}

1PG Scholar, Department of Swasthavritta, RGGPG Ayurvedic College and Hospital Paprola 176115, Distt. Kangra (H.P.) India

${ }^{2}$ Lecturer, Department of Swasthavritta, RGGPG Ayurvedic College and Hospital Paprola 176115,

Distt. Kangra (H.P) India

Corresponding Author:akankshadogra35@gmail.com

https://doi.org/10.46607/iamj3009092021

(Published Online: September 2021)

Open Access

(C) International Ayurvedic Medical Journal, India 2021

Article Received:18/08//2021 - Peer Reviewed:02/09/2021 - Accepted for Publication:03/09/2021

Check for updates

\begin{abstract}
Ayurveda is a holistic science and emphasizes preserving and promoting the health of healthy individuals besides giving methods for the treatment of various diseases. It is more a 'way of life' and describes methods for promotion, prolongation, and maintenance of positive health. In the present era, people are spending most of their time sitting at the workplace i.e., living a sedentary lifestyle. It is very necessary to maintain health and prevent diseases as people leading a sedentary lifestyle are more susceptible to lifestyle diseases. Balanced Dosha promotes health and imbalanced Dosha leads to the diseased condition. Moreover, a balanced diet is required by the body to work efficiently. Without a balanced diet, the body is more prone to disease, infection, fatigue, and low performance. So, health can be maintained by intake of balanced and Tridosha Shamaka diet. The concept of Nitya Prayunjeeta (used daily) AaharaDravya has been given by Aacharya Charaka for the maintenance and promotion of health. Here, an effort has been made to establish the concept of Nitya Prayunjeet Aahara Dravya as Tridosha Shamaka diet and Balanced diet.
\end{abstract}

Keywords: Nitya Prayunjeet, TridoshaShamana, Balanced diet 


\section{INTRODUCTION}

Ayurveda is an ancient science of life since time immemorial. Ayurveda, apart from providing various therapeutic measures for diseases, emphasizes maintenance, promotion of health and prevention of diseases through diet and lifestyle regimens. Aacharya Vagbhatta has mentioned that Vata, Pitta and Kapha are the three Dosha of body. The perfect balance of these three Dosha leads to "health" and the imbalance of these Dosha leads to "diseases". ${ }^{1}$ The prime objective of Ayurveda is to counteract the imbalance of Tridosha, which can only be achieved by the suitable administration of Aahara. Aacharya Charaka has described Nitya Prayunjeeta (consumed daily) Aahara Dravya which are Shashtika (Rice), Shali (Rice), Mudga (Green gram), Saindhava (Rock salt), Amalaki (Indian Gooseberry), Yava (Barley), Antariksha Jala ( Rainwater), Paya (Cow's milk), Sarpi (Cow's ghee), Jangala Mansa (Meat of animals dwelling in arid climate) and Madhu (Honey). ${ }^{2}$ AacharyaVagbhatta has explained some extra Dravya like Godhuma (Wheat), Sunishannaka (Marsilea minuta), Jeevanti (Leptadenia reticulata), Bala Mulaka (Young radish), Vastuka (Chenopodium album), Pathya (Terminalia chebula), Mridwika (Dried grapes), Patola (Pointed Gourd), Sharkara (sugar), Dadima(Punica granatum). ${ }^{3}$ These Aahara Dravya promote the health of an individual and prevent diseases. $^{4}$

\section{Aim and Objectives}

1. To establish the concept of Nitya Prayunjeet Aahara Dravya as Tridosha balancing diet i.e. health-promoting diet.

2. To establish the concept of Nitya PrayunjeetAahara Dravya as a balanced diet.

\section{Materials and methods}

Ayurvedic literature like Charaka Samhita, Ashtanga Hridya and Bhavaprakasha Nighantu related to this topic are studied. Various articles and journals have also been searched.

Concept of Nitya Prayunjeet Aahara Dravya as Tridosha balancing diet- Aahara Dravya mentioned as Nitya Prayunjeet have different pharmacological properties. So, they have a different effect on Tridosha. The effect of these Aahara Dravya on Tridosha is described below:

Shastika -It is Laghu and Snigdha in Guna, Balya, Mridu, Jwaranashaka and Tridoshanashaka. ${ }^{5}$

Shali-Shali is Madhura and Kashaya in Rasa, Laghu, Snigdha, Sheeta, Ruchya, Balya, Kanthya, Vrishya, Brihana, AlpaVata-KaphaKarka and Pittanashaka. ${ }^{6}$

Mudga - It is Ruksha, Laghu, Sheeta, Grahi, KaphaPitta Nashaka, AlpaVatavardhaka, Netrya and Jwaranashaka. ${ }^{7}$

Saindhava- Saindhava Lavana is Deepana, Pachana, Laghu, Snigdha, Ruchya, Sheeta, Vrishya, Netrya and Tridoshahar

Amalaki- It is Sheeta, Raktapitta Nashaka, Prameha Nashaka, Vrishya, Rasayana and Tridoshanashaka. ${ }^{9}$

Yava - Yava is Kashaya and Madhura in Rasa, Sheeta, Katu in Vipaka, Ruksha, Agnivardhaka, Guru, Balya, Shwasa-KasaNashaka, MalaKarka, VataKarka and Shleshma-PittaNashaka. ${ }^{10}$

Antriksha Jala-It is Laghu, Saumya, Rasayana, Balya, Triptikarka, Pachaka, DahaNashaka, Tandranashaka and Tridoshanashaka. ${ }^{11}$

Paya - Paya is Madhura in Rasa and Vipaka, Sheeta, Snigdha, Guru, Vata-Pitta Nashaka and SarvarogaNashaka. ${ }^{12}$

Sarpi-Sarpi is Madhura in Vipaka, Sheeta, Guru, Chakshushya, Vrishya, Agnivardhaka, Ojavardhaka,Balya, Ayushya, Rasayana and Tridoshanasha$\mathrm{ka}^{13}$

Jangala Mansa - It is Madhura, Sheeta, Kashaya, Katu in Vipaka, Balya, Vrishya, Tridoshanashaka and Laghu. ${ }^{14}$

Madhu-Madhu is Madhura in Rasa, Kashaya in Anurasa, Sheeta, Laghu, Ruksha, Grahi, Netrya, Agnideepaka, Vrishya, Vishada, Rochana, AlpaVatakarka, Kapha-PittaNashaka, PramehaNashaka, Vamana Nashaka and KshyaNashaka. ${ }^{15}$

Godhuma- It is Madhura in Rasa, Sheeta, Guru, Snigdha, Vata-PittaNashaka, Kaphavardhaka, Balya, Brihana and Ruchya. ${ }^{16}$ 
Sunishannaka-It is Madhura and Kashaya in Rasa, Sheeta is Veerya, Laghu and Ruksha in Guna, Deepana, Vrishya, Ruchya, Meda Nashaka and Tridoshanashaka. ${ }^{17}$

Jeevanti-It is Sheeta in Veerya, Snigdha and Laghu in Guna, Rasayana, Balakraka, Chakshushya, Grahiand Tridoshanashaka. ${ }^{18}$

BalaMulaka- BalaMulaka is Katu in Rasa, Laghu, Ruchya, Pachaka, Jwara Nashaka, Shwasa Nashaka and Tridoshanashaka. ${ }^{19}$

Vastuka-It is Katu in Vipaka, Laghu, Deepana, Pachana, Ruchya, Saraka, RaktapittaNashaka, ArshaNashaka and TridoshaNashaka. ${ }^{20}$

Pathya- It is KashayaRasa Dominant, Madhura in Vipaka, Ruksha, Ushna in Veerya, Laghu, Rasayana, Netrya, Anulomaka and Tridoshanashaka. ${ }^{21}$
Mridwika - It is Madhura and Kashaya in Rasa, Madhura in Vipaka, Sheeta, Saraka, Netrya, Guru, Ruchya, Kaphavardhaka, VataPittaNashaka, Trisha Nashaka and JwaraNashaka. ${ }^{22}$

Patola- Patola is Laghu and Snigdha in Guna, Ushna in Veerya, Pachaka, Deepana, Vrishya, Hridya, JwaraNashaka and Tridoshanashaka. ${ }^{23}$

Sharkara- Itis Madhura, Sheeta, VataPittaNashaka, DahaNashaka, MurchhaNashaka, JwaraNashaka and ChhardiNashaka. ${ }^{24}$

Dadima - Dadima is Madhura in Rasa, Kashaya in Anurasa, Laghu and Snigdha in Guna, Grahi, Balya, Hridya, Medhya, Jwara Nashaka and Tridosha Shamaka. $^{25}$

Table 1: Tridosha effect of Nitya Prayunjeet Aahara Dravya is summarized in this table:

\begin{tabular}{|l|l|}
\hline Aahara Dravya & Effect onDosha \\
\hline Shashtika & Vata-Pitta Shamaka \\
\hline Shali & Pitta Shamaka and Kinchita Vata Kapha Vardhaka \\
\hline Mudga & Kapha-Pitta Shamaka and Kinchita Vatakarka \\
\hline Saindhava & Tridsoha Nashaka \\
\hline Amalaki & Tridosha Shamaka \\
\hline Yava & Kapha - Pitta Shamaka and Vata Vardhaka \\
\hline Paya & Vata-Pitta Shamaka \\
\hline Sarpi & Tridosha Shamaka \\
\hline Jangal Mansa & Tridosha Nashaka \\
\hline Madhu & Kapha - Pitta Shamaka and Kinchita Vatakarka \\
\hline Godhuma & Vata-PittaNashaka, Kaphavardhaka \\
\hline Sunishannaka & Tridoshanashaka \\
\hline Jeevanti & Tridoshanashaka \\
\hline BalaMulaka & Tridoshanashaka \\
\hline Vastuka & TridoshaNashaka \\
\hline Pathya & Tridoshanashaka \\
\hline Mridwika & Kaphavardhaka, VataPittaNashaka \\
\hline Patola & Tridoshanashaka \\
\hline Sharkara & VataPittaNashaka \\
\hline Dadima & TridoshaShamaka \\
\hline
\end{tabular}

Concept of a balanced diet -A balanced diet is defined as one which contains a variety of foods in such quantities and proportions that the need for energy, amino acids, vitamins, minerals, fats, carbohydrates and other nutrients is adequately met for maintaining health, vitality and general well-being and also makes a small provision for extra nutrients to withstand the short duration of leanness. ${ }^{26}$ From this definition of a Balanced diet it is clear that one must take a balanced diet daily to maintain health. In the present era, most 
people are living a sedentary lifestyle. So, the need of the hour is to establish the concept of a balanced diet in persons having a sedentary lifestyle as this is the main cause of non-communicable diseases. A balanced diet can be understood in terms of daily calorific intake and daily requirement of macronutrients.
Due to urbanization and increasing workload sedentary lifestyle is common. So, here Recommended Dietary Allowances for a person living a sedentary lifestyle is taken into consideration.

Table 2: Recommended Dietary Allowances (RDA) for Energy, Protein, Fat for Indians - $2010^{27}$

\begin{tabular}{|l|l|l|l|l|l|}
\hline Gender & Category & Body weight $(\mathrm{kg})$ & Net Energy $(\mathrm{kcal} / \mathrm{d})$ & Protein $(\mathrm{g} / \mathrm{d})$ & Visible Fat $(\mathrm{g} / \mathrm{d})$ \\
\hline Men & Sedentary Work & 60 & 2320 & 60 & 25 \\
\hline
\end{tabular}

Table 3: Balanced Diet for Adults - Sedentary Activity ${ }^{28}$

\begin{tabular}{|l|l|l|}
\hline & g/portion & No. of portions \\
\hline Cereals \& millets & 30 & 12.5 \\
\hline Pulses & 30 & 2.5 \\
\hline Milk \& milk products & $100 \mathrm{ml}$ & 3 \\
\hline Roots \& tubers & 100 & 2 \\
\hline Green leafy vegetables & 100 & 1 \\
\hline Other vegetables & 100 & 2 \\
\hline Fruits & 100 & 1 \\
\hline Sugar & 5 & 4 \\
\hline Fat & 5 & 5 \\
\hline
\end{tabular}

To calculate the daily requirement of any food group for an individual, multiply grams per portion by

\section{several portions.}

Here, an effort has been done to calculate the daily requirement of different food groups along with protein content, fat content \& energy production.

Cereals and millets - Cereals are the main sources of energy. They are contributing significant quantities of proteins, (6-12\%), minerals and B-group vitamins. ${ }^{29}$ For an adult having a sedentary lifestyle, $30 \mathrm{~g} /$ portion of cereals and millets is to be consumed i.e. 375 gm daily. Among Nitya Prayunjeet Aahara Dravya, Rice, Barley and Wheat are to be included in Cereals and Millets. The total amount of these should not exceed 375 gm. Barley is not commonly used. 175 gm wheat \& $200 \mathrm{gm}$ rice can be consumed daily. $175 \mathrm{gm}$ of wheat contains $21 \mathrm{gm}$ protein, $2.98 \mathrm{gm}$ fat \& $596 \mathrm{kcal}$ energy. $200 \mathrm{gm}$ rice has $15 \mathrm{gm}$ protein, 2 gm fat and provides $692 \mathrm{kcal}$ energy.

Pulses - Pulses contain $20-25 \%$ of proteins \& are rich in minerals and B-group vitamins such as ribo- flavin and thiamine..$^{30}$ Daily requirement of pulses for an adult having a sedentary lifestyle is $75 \mathrm{gms}$. Only one pulse i.e. green gram is being mentioned under Nitya Prayunjeet Aahara Dravya. 75 gms of Green gram contains $18 \mathrm{gm}$ protein, $0.98 \mathrm{gm}$ fat \& provides $250 \mathrm{kcal}$ energy.

Milk and milk products - Milk is a good source of proteins, fats, sugars, vitamins, and minerals. ${ }^{31}$ Total $300 \mathrm{ml}$ of milk and milk products are required daily. Here, cow's milk is taken under consideration as described in Nitya Prayunjeet Aahara Dravya. $300 \mathrm{ml}$ of cow's milk contains $9.6 \mathrm{~g}$ of protein and $12.3 \mathrm{~g}$ of fat and provides $201 \mathrm{kcal}$ energy.

Vegetables - Vegetables usually have a large water content, low energy and protein content and varying amounts of "dietary fibre". ${ }^{32}$

- Green leafy vegetables - These are good sources of carotenes, calcium, iron and Vit. C. they are also fairly good sources of riboflavin, folic acid, and many other micronutrients. Marselia, Leptadenia and Bathua are the green leafy vegetables described among Nitya Prayunjeet Dravya. 
Marselia and leptadenia are not easily available. Moreover, only a few people are aware of them. So, here only Bathua is taken into consideration. $100 \mathrm{gm}$ of Green leafy vegetables are required daily. 100 gm of Bathua contains 3.7 gm of protein, $0.4 \mathrm{gm}$ of fat and provides $30 \mathrm{kcal}$ of energy.

- Roots \& tubers - In general roots and tubers are poor in protein, minerals and vitamins. $200 \mathrm{gm}$ of roots and tubers are daily required by an adult man having a sedentary lifestyle. Only Radish among roots is mentioned under Nitya Prayunjeet Aahara Dravya. 200 gm of Radish contains 1.4 gm protein, $0.2 \mathrm{gm}$ fat and yields $34 \mathrm{kcal}$ of energy.

- Other Vegetables - These are good sources of minerals and vitamins. 200 gm vegetables are required daily for an adult having a sedentary lifestyle. $200 \mathrm{gm}$ of Patola contains $4 \mathrm{gm}$ of protein, $0.6 \mathrm{gm}$ of fat and yields $40 \mathrm{kcal}$ of energy.

Fruits - Fruits are good sources of vitamins and minerals. ${ }^{33}$ Fruits described in Nitya Prayunjeet Dravya are Dadima, Amalaki, Pathya \& Mridwika. 100 gm of fruits are required daily. So, the total amount of either one fruit or more than one fruit should not exceed the required amount. $20 \mathrm{gm}$ Amla, 10 gm raisins and $70 \mathrm{gm}$ pomegranate can be used daily. 20 gm of Amla has $0.1 \mathrm{gm}$ protein, $0.02 \mathrm{gm}$ fat and provides $11.6 \mathrm{kcal}$ of energy. $10 \mathrm{gm}$ of raisins contains $0.18 \mathrm{gm}$ protein, $0.03 \mathrm{gm}$ fat $\&$ it provides $30.8 \mathrm{kcal}$ of energy. $70 \mathrm{gm}$ pomegranate provides $45.5 \mathrm{kcal}$ energy, contains $1.12 \mathrm{gm}$ protein $\& 0.07 \mathrm{gm}$ fat.

Sugar-Sugar is a rich source of carbohydrates. ${ }^{34}$ Total 20 grams of sugar is required by an adult man leading a sedentary life. Here, honey \& sugar are mentioned. $15 \mathrm{gm}$ of Sugar is enough for beverages and $5 \mathrm{gm}$ of Honey is enough to be used in one glass of lukewarm lemon water. 15 gm of sugar provides $75.4 \mathrm{kcal}$ energy, no protein \& no fat.5 gm of honey contains $0.02 \mathrm{gm}$ protein, no fat and yields $15.95 \mathrm{kcal}$ energy.

Fat-Fats are good sources of energy and fat-soluble vitamins. $^{35}$

25 gm of visible fat is required daily. Cow's Ghee is described in Nitya Prayunjeet Aahara Dravya. $25 \mathrm{gm}$ of Cow's Ghee provides 225 kcal energy.

Table 4: Calorific value and protein content calculation of Nitya Prayunjeet Dravya

\begin{tabular}{|l|l|l|l|}
\hline & Quantity & Energy (Kcal) & Protein(gm) \\
\hline Cereals \& millets & $375 \mathrm{gm}$ & 1288 & 36 \\
\hline Pulses & $75 \mathrm{gm}$ & 250 & 18 \\
\hline Milk \& milk products & $300 \mathrm{ml}$ & 201 & 9.6 \\
\hline Roots \& tubers & $200 \mathrm{gm}$ & 34 & 1.4 \\
\hline Green leafy vegetables & $100 \mathrm{gm}$ & 30 & 3.7 \\
\hline Other vegetables & $200 \mathrm{gm}$ & 40 & 4 \\
\hline Fruits & $100 \mathrm{gm}$ & 87.9 & 1.4 \\
\hline Sugar & $20 \mathrm{gm}$ & 91.35 & 0.02 \\
\hline Fat & $25 \mathrm{gm}$ & 225 & 0 \\
\hline Total & & $2247 \mathrm{kcal}$ & 74.12 \\
\hline
\end{tabular}

*Note - For Non-Vegetarians - Substitute one pulse portion with one portion of egg/meat/chicken/fish Energy obtained from Nitya Prayunjeet Aahara Dra$v y a$ is approximately equal to the energy required by an adult man having a sedentary lifestyle. Protein content obtained from these Aahara Dravya will be approximately equal to the protein required as cooking these will reduce the protein content significantly.

\section{DISCUSSION}

A balanced diet provides an adequate intake of energy and nutrients for the maintenance of the body and therefore good health. A diet can easily be adequate for normal body functioning yet may not be a balanced diet. An ideal human diet contains fat, protein, carbohydrates, vitamins, minerals, and water all in correct proportions. Malnutrition results from an un- 
balanced diet, this can be due to an excess of some dietary components and lack of other components, not just a complete lack of food. Energy is provided by carbohydrates, fats and proteins. Proteins are a provider of energy in an emergency but are primarily used as building blocks for the growth and repair of many body tissues. We also need much smaller amounts of other nutrients, such as vitamins and minerals. Despite the small quantities needed these are essential to provide a healthy diet as they have specific roles in metabolic reactions and as structural components. So, for perfect functioning, the body requires both macronutrients and micronutrients in adequate amounts.

\section{CONCLUSION}

The maximum of Aahara Dravya mentioned in Nitya Prayunjeet have TridoshaShamaka effect. Balanced Tridosha will help in the promotion of health and prevention of diseases. A balanced diet is required daily for the maintenance of health and prevention of diseases. By consuming Nitya Prayunjeet Aahara Dravya, need for energy, amino acids, vitamins, minerals, fats, carbohydrates, and other nutrients is adequately met.

\section{REFERENCES}

1. Astangahrdayam of Vagbhata Edited with the 'Vidyotini' Hindi Commentary ByKaviraj Atrideva Gupta Chaukhambha Prakashan Varanasi Sutrasthana $\mathrm{Ch}$ 1/6-7 Pg 4

2. Caraka Samhita of Agnivesha with Elaborated Vidyotini Hindi Commentary Part -1 Chaukhambha Bharati Academy Ch 5/12 Pg 106

3. Astangahrdayam of Vagbhatta Edited with the 'Vidyotini' Hindi Commentary By Kaviraja Atrideva Gupta Chaukhambha Prakashan Varanasi Sutrasthana Ch 8/42-43 Pg 102

4. Caraka Samhita of Agnivesa with Elaborated Vidyotini Hindi Commentary Part -1 Chaukhambha Bharati Academy Ch 5/13 Pg 107

5. Bhavaprakasha Nighantu of Sribhava Misra Edited with the Vidyotini Hindi Commentary, Notes and Appendix First Part Chaukhambha Sanskrit BhawanCh 8/25-26 Pg- 639
6. Bhavaprakasha Nighantu of Sribhava Misra Edited with the Vidyotini Hindi Commentary, Notes and Appendix First Part Chaukhambha Sanskrit Bhawan Ch 8/7 Pg- 635

7. Bhavaprakasha Nighantu of Sribhava Misra Edited with the Vidyotini Hindi Commentary, Notes and Appendix First Part Chaukhambha Sanskrit Bhawan Ch 8/38 Pg- 643

8. Bhavaprakasha Nighantu of Sribhava Misra Edited with the Vidyotini Hindi Commentary, Notes and Appendix First Part Chaukhambha Sanskrit Bhawan Ch 1/241 Pg- 154

9. Bhavaprakasha Nighantu of Sribhava Misra Edited with the Vidyotini Hindi Commentary, Notes and Appendix First Part Chaukhambha Sanskrit Bhawan Ch 1/39 Pg- 10

10. Bhavaprakasha Nighantu of Sribhava Misra Edited with the Vidyotini Hindi Commentary, Notes and Appendix First Part Chaukhambha Sanskrit Bhawan Ch 9/28-30 Pg- 640

11. Bhavaprakasha Nighantu of Sribhava Misra Edited with the Vidyotini Hindi Commentary, Notes and Appendix First Part Chaukhambha Sanskrit Bhawan Ch 12/7-8 Pg-747

12. Bhavaprakasha Nighantu of Sribhava Misra Edited with the Vidyotini Hindi Commentary, Notes and Appendix First Part Chaukhambha Sanskrit Bhawan Ch 13/7-8 Pg-759

13. Bhavaprakasha Nighantu of Sribhava Misra Edited with the Vidyotini Hindi Commentary, Notes and Appendix First Part Chaukhambha Sanskrit Bhawan Ch 17/4-6 Pg-775

14. Bhavaprakasha Nighantu of Sribhava Misra Edited with the Vidyotini Hindi Commentary, Notes and Appendix First Part Chaukhambha Sanskrit Bhawan Ch 10/20-22 Pg-707

15. Bhavaprakasha Nighantu of Sribhava Misra Edited with the Vidyotini Hindi Commentary, Notes and Appendix First Part Chaukhambha Sanskrit Bhawan Ch 21/1-5 Pg-788

16. Bhavaprakasha Nighantu of Sribhava Misra Edited with the Vidyotini Hindi Commentary, Notes and Appendix First Part Chaukhambha Sanskrit Bhawan Ch 8/33-34 Pg-642

17. Bhavaprakasha Nighantu of Sribhava Misra Edited with the Vidyotini Hindi Commentary, Notes and Appendix First Part Chaukhambha Sanskrit Bhawan Ch 9/31-32 Pg-674 
18. Bhavaprakasha Nighantu of Sribhava Misra Edited with the Vidyotini Hindi Commentary, Notes and Appendix First Part Chaukhambha Sanskrit Bhawan Ch 3/51 Pg-295

19. Bhavaprakasha Nighantu of Sribhava Misra Edited with the Vidyotini Hindi Commentary, Notes and Appendix First Part Chaukhambha Sanskrit Bhawan Ch 9 /101-102Pg-696

20. Bhavaprakasha Nighantu of Sribhava Misra Edited with the Vidyotini Hindi Commentary, Notes and Appendix First Part Chaukhambha Sanskrit Bhawan Ch 9/6-7 Pg-663

21. Bhavaprakasha Nighantu of Sribhava Misra Edited with the Vidyotini Hindi Commentary, Notes and Appendix First Part Chaukhambha Sanskrit Bhawan Ch 1/19-22 Pg-5

22. Bhavaprakasha Nighantu of Sribhava Misra Edited with the Vidyotini Hindi Commentary, Notes and Appendix First Part Chaukhambha Sanskrit Bhawan Ch 6/109-113 Pg-585

23. Bhavaprakasha Nighantu of Sribhava Misra Edited with the Vidyotini Hindi Commentary, Notes and Appendix First Part Chaukhambha Sanskrit Bhawan Ch 9/70 Pg-686

24. Bhavaprakasha Nighantu of Sribhava Misra Edited with the Vidyotini Hindi Commentary, Notes and Appendix First Part Chaukhambha Sanskrit Bhawan Ch 20/30 Pg-796

25. Bhavaprakasha Nighantu of Sribhava Misra Edited with the Vidyotini Hindi Commentary, Notes and Appendix First Part Chaukhambha Sanskrit Bhawan Ch 9/102-104 Pg-582
26. Park's Textbook of Preventive and Social Medicine $25^{\text {th }}$ Edition By M/s Banarsidas Bhanot Publishers Ch 11 Pg 694

27. Park's Textbook of Preventive and Social Medicine $25^{\text {th }}$ Edition By M/s Banarsidas Bhanot Publishers Ch 11 Pg 693

28. Dietary Guidelines for Indians - A Manual Published by National Institute of NutritionAnnexure 2 Page 86

29. Park's Textbook of Preventive and Social Medicine $25^{\text {th }}$ Edition By M/s Banarsidas Bhanot Publishers Ch $11 \mathrm{Pg} 683$

30. Park's Textbook of Preventive and Social Medicine $25^{\text {th }}$ Edition By M/s Banarsidas Bhanot Publishers Ch 11 Pg 685

31. Park's Textbook of Preventive and Social Medicine $25^{\text {th }}$ Edition By M/s Banarsidas Bhanot Publishers Ch 11 Pg 687

32. Park's Textbook of Preventive and Social Medicine $25^{\text {th }}$ Edition By M/s Banarsidas Bhanot Publishers Ch $11 \mathrm{Pg}$ 685-686

33. Park's Textbook of Preventive and Social Medicine $25^{\text {th }}$ Edition By M/s Banarsidas Bhanot Publishers Ch 11 Pg 686

34. Park's Textbook of Preventive and Social Medicine $25^{\text {th }}$ Edition By M/s Banarsidas Bhanot Publishers Ch $11 \mathrm{Pg} 688$

35. Park's Textbook of Preventive and Social Medicine $25^{\text {th }}$ Edition By M/s Banarsidas Bhanot Publishers Ch $11 \mathrm{Pg} 688$

\section{Source of Support: Nil \\ Conflict of Interest: None Declared}

How to cite this URL: Dogra Akanksha \& Jagota Ankush: Evaluation Of Nitya Prayunjeet Aahara Dravya Of And Its Resemblance To Balanced Diet In Current Scenario. International Ayurvedic Medical Journal \{online\} 2021 \{cited September 2021\} Available from: http://www.iamj.in/posts/images/upload/2122_2128.pdf 